\title{
Effect of arbuscular mycorrhizal fungi on young vines in copper-contaminated soil
}

\author{
Vítor Gabriel Ambrosini ${ }^{1}$, Joana Gerent Voges ${ }^{1}$, Ludiana Canton ${ }^{1}$, \\ Rafael da Rosa Couto ${ }^{1}$, Paulo Ademar Avelar Ferreira ${ }^{2}$, Jucinei José Comin ${ }^{1}$, \\ George Wellington Bastos de Melo ${ }^{3}$, Gustavo Brunetto ${ }^{2}$, \\ Cláudio Roberto Fonsêca Sousa Soares ${ }^{1}$ \\ ${ }^{1}$ Universidade Federal de Santa Catarina, Florianópolis, SC, Brazil. \\ ${ }^{2}$ Universidade Federal de Santa Maria, Santa Maria, RS, Brazil. \\ ${ }^{3}$ Empresa Brasileira de Pesquisa Agropecuária, Bento Gonçalves, RS, Brazil.
}

Submitted: July 22, 2014; Approved: October 9, 2014.

\begin{abstract}
High copper $(\mathrm{Cu})$ levels in uprooted old vineyard soils may cause toxicity in transplanted young vines, although such toxicity may be reduced by inoculating plants with arbuscular mycorrhizal fungi (AMF). The objective of this study was to evaluate the effects of AMF on the plant growth, chlorophyll contents, mycorrhizal colonization, and $\mathrm{Cu}$ and phosphorus $(\mathrm{P})$ absorption in young vines cultivated in a vineyard soil contaminated by $\mathrm{Cu}$. Commercial vineyard soil with high $\mathrm{Cu}$ levels was placed in plastic tubes and transplanted with young vines, which were inoculated with six AMF species (Dentiscutata heterogama, Gigaspora gigantea, Acaulospora morrowiae, A. colombiana, Rhizophagus clarus, R. irregularis) and a control treatment on randomized blocks with 12 replicates. After 130 days, the mycorrhizal colonization, root and shoot dry matter (DM), height increment, $\mathrm{P}$ and $\mathrm{Cu}$ absorption, and chlorophyll contents were evaluated. The height increment, shoot DM and chlorophyll contents were not promoted by AMF, although the root DM was increased by $R$. clarus and $R$. irregularis, which had the greatest mycorrhizal colonization and $\mathrm{P}$ uptake. AMF increased $\mathrm{Cu}$ absorption but decreased its transport to shoots. Thus, AMF species, particularly $R$. clarus and $R$. irregularis, contribute to the establishment of young vines exposed to high $\mathrm{Cu}$ levels.
\end{abstract}

Key words: mycorrhizae, trace elements, phosphorus, Vitis sp.

\section{Introduction}

Over time, continuous foliar applications of fungicides and mixtures containing copper $(\mathrm{Cu})$ for the preventive control of fungal diseases in productive adult vines (Vitis sp.) have caused the accumulation of trace elements in vineyard soils (Nogueirol et al., 2010; Brunetto et al., 2014). Subsequent to the uprooting of old vineyards, which occurs with decreased grape production, the soil is plowed for the transplantation of young vines, and this plowing stimulates the oxidation of soil organic matter (SOM) (Campos et al., 2013), especially in sandy soils (Chivenge et al., 2011), thereby increasing $\mathrm{Cu}$ availability because much of this trace element is bound to the SOM (Brunetto et al., 2014).
Transplanted young vines may show restricted root growth, including decreased length and root branch number (Lequeux et al., 2010), root cuticle damage (Sheldon and Menzies, 2005), and root cracks (Michaud et al., 2008), because of the high levels of available $\mathrm{Cu}$. Therefore, decreased water and nutrient absorption through the roots may occur, which may reduce tissue nutrient levels and plant growth (Kopittke et al., 2009). Furthermore, plant exposure to high $\mathrm{Cu}$ concentrations may reduce the level of chlorophyll in the leaves and inhibit photosynthesis (Yruela, 2009). Thus, the use of strategies to minimize $\mathrm{Cu}$ toxicity to young vines is necessary, especially in sandy soils with low organic matter levels where 1:1 clay mineral pre- 
dominates and trace elements, including $\mathrm{Cu}$, tend to be more available (Brunetto et al., 2014).

Mutualistic associations between arbuscular mycorrhizal fungi (AMF) and plant root systems are among the possible methods of reducing $\mathrm{Cu}$ toxicity. AMF isolates exhibit strategies that allow them to tolerate high levels of soil trace elements and ensure their own survival as well as the survival of the plant with which they are associated (Ferrol et al., 2009). For example, AMF may release substances, including glomalin, into the soil organic layer, and these substances may form complexes with trace elements that decrease their availability to plants (Bedini et al., 2010). Furthermore, AMF can store $\mathrm{Cu}$ in cellular compartments, including spores and vesicles, where the metabolic rate is reduced, thus decreasing the effect of $\mathrm{Cu}$ on plant metabolism, which benefits plant growth and the AMF (Ferrol et al., 2009; Cornejo et al., 2013).

Furthermore, the colonization of the root cortex of higher plants by AMF provides an increased interface between roots and soil and functions as a site of nutrient exchange between plants and AMF (Ferrol and Pérez-Tienda, 2009). Thus, nutrients with low mobility in soils, such as phosphorus (P), may be absorbed in greater amounts by roots, which improves the nutritional state of the plants (Soares and Siqueira, 2008; Andrade et al., 2010; Anzanello et al., 2011). Such improvements cause the rapid growth of young vines, which is desired because the start of grape production may be accelerated. Concurrently, the increased root $\mathrm{P}$ levels may promote the formation of metalphosphate compounds with low mobility characteristics, which would reduce trace element transport to the shoots and allow the elements to accumulate in the roots, reducing toxicity in the shoots (Soares and Siqueira, 2008).

Increased $\mathrm{P}$ in plants also favors the production of plant biomass and increased photosynthetic rates (Siqueira et al., 2008). In plants exposed to high levels of trace elements, $\mathrm{P}$ supplied by inoculation with AMF promotes increased leaf area and chlorophyll $a$ and $b$ contents in the leaves, which increases the interception of light by leaves and the production of soluble sugars and proteins and contributes to stress tolerance by trace elements (Latef, 2011; Rahmaty and Khara, 2011).

Thus, AMF have several mechanisms that contribute to the growth of plant species when exposed to potentially toxic elements, such as $\mathrm{Cu}$, and inoculation with these fungi can play an important role in the absorption of $\mathrm{P}$, which promotes tolerance in plants exposed to these elements. The objective of this study was to evaluate the effects of inoculation with AMF on the growth, chlorophyll contents, mycorrhizal colonization, and $\mathrm{Cu}$ and $\mathrm{P}$ absorption of young vines cultivated in vineyard soils with high $\mathrm{Cu}$ levels.

\section{Materials and Methods}

The experiment was conducted in a greenhouse using soil collected from the $0-20 \mathrm{~cm}$ layer in a commercial vineyard located in Santana do Livramento, in the Campanha Gaúcha region of the state of Rio Grande do Sul (RS), with 40 years of cultivation and a long history of foliar copper fungicide application. The soil was classified as Typic Hapludalf (Soil Survey Staff, 2006) with a sandy surface texture, had a predominance of 1:1 clay minerals, and exhibited the following characteristics: clay, silt, and sand levels of 44, 64, and $892 \mathrm{~g} \mathrm{~kg}^{-1}$, respectively; $18.5 \mathrm{~g} \mathrm{~kg}^{-1}$ SOM (EMBRAPA, 1999); 5.7 pH in water (1:1); exchangeable $\mathrm{Al}, \mathrm{Ca}$, and $\mathrm{Mg}$ (extracted with $1 \mathrm{~mol} \mathrm{~L}^{-1} \mathrm{KCl}$ ) concentrations of $0.0,1.3$, and $0.3 \mathrm{cmol}_{\mathrm{c}} \mathrm{kg}^{-1}$, respectively; $28.4 \mathrm{mg} \mathrm{kg}^{-1}$ available P; and $83.5 \mathrm{mg} \mathrm{kg}^{-1}$ exchangeable $\mathrm{K}$ (Tedesco et al., 1995). The soil $\mathrm{Cu}$ level extracted with $0.1 \mathrm{~mol} \mathrm{~L}^{-1} \mathrm{HCl}$ was $46.2 \mathrm{mg} \mathrm{kg}^{-1}$ (Tedesco et al., 1995), which was 100 times greater than the high value $(>0.4 \mathrm{mg}$ $\mathrm{dm}^{-3}$ ) established by the Comissão de Química e Fertilidade do Solo do Rio Grande do Sul e Santa Catarina (CQFS-RS/SC, 2004).

The soil was air-dried following collection, sieved through a $2 \mathrm{~mm}$ mesh, homogenized, placed in plastic $300 \mathrm{~cm}^{3}$ tubes, and then sterilized in an autoclave at $121^{\circ} \mathrm{C}$ for two hours. The vine seedlings (P1103 rootstock - Vitis berlandieri $x$ Vitis rupestris) were produced by in vitro micropropagation and acclimatized in sterile substrate. The explants were cultivated in test tubes $(110 \mathrm{~mm} \times 23 \mathrm{~mm})$ containing $10 \mathrm{~mL}$ culture medium Galzy (1964) in a controlled environment room at $23{ }^{\circ} \mathrm{C} \pm 2$ with a $16 \mathrm{~h}$ light day $^{-1}$ photoperiod with photosynthetically active radiation of $75 \mu \mathrm{mol}$ photon $\mathrm{m}^{-2} \mathrm{~s}^{-1}$ for 30 days. Afterward, the plants were transferred to $200 \mathrm{~mL}$ horticultural substrate and fine vermiculite (1:1 ratio), and they were cultivated in a controlled environment room at $25{ }^{\circ} \mathrm{C} \pm 4$ with a $12 \mathrm{~h}$ light day $^{-1}$ photoperiod with photosynthetically active radiation of $100 \mu \mathrm{mol}$ photon $\mathrm{m}^{-2} \mathrm{~s}^{-1}$ for 30 days. Following acclimatization, the plants were selected for height and vigor, transplanted to plastic tubes, and then inoculated with $10 \mathrm{~mL}$ soil-inoculum containing AMF propagules.

The experimental design consisted of randomized blocks with inoculation treatments of six species of AMF (Dentiscutata heterogama - UFSC 08, Gigaspora gigantea - UFSC 04, Acaulospora morrowiae - UFSC 16, Acaulospora colombiana - UFSC 29, Rhizophagus clarus UFSC 14, and Rhizophagus irregularis - DAOM 181602) and a control treatment without AMF inoculation. Twelve replicates were used per treatment. The AMF were maintained in a greenhouse in pots containing Brachiaria decumbens, and the soil inoculum contained 918, 6, 1316, 966, 496 and 492 spores per $50 \mathrm{~mL}$ of D. heterogama, G. 
gigantea, A. morrowiae, A. colombiana, $R$. clarus and $R$. irregularis, respectively.

Following transplantation, the seedlings received $20 \mathrm{~mL}$ of Long Ashton nutrient solution (Resh, 1997), modified to supply only $10 \%$ of the original $\mathrm{P}$ concentration, $0.5 \mathrm{mg} \mathrm{dm}^{-3} \mathrm{~B}\left(\mathrm{H}_{3} \mathrm{BO}_{3}\right)$, and $0.1 \mathrm{mg} \mathrm{dm}^{-3} \mathrm{Mo}$ $\left(\left(\mathrm{NH}_{4}\right)_{6} \mathrm{Mo}_{7} \mathrm{O}_{24} \cdot 4 \mathrm{H}_{2} \mathrm{O}\right)$. Throughout the cultivation, $300 \mathrm{mg} \mathrm{dm}^{-3} \mathrm{~N}$ and $\mathrm{K}$ were added in the form of $\mathrm{NH}_{4} \mathrm{NO}_{3}$ and $\mathrm{K}_{2} \mathrm{SO}_{4}$, respectively, with the $\mathrm{N}$ dose applied in installments at 1, 7, and 12 weeks after transplantation. Furthermore, $160 \mathrm{mg} \mathrm{dm}^{-3} \mathrm{Ca}\left(\mathrm{CaSO}_{4} \cdot 2 \mathrm{H}_{2} \mathrm{O}\right)$ and $60 \mathrm{mg} \mathrm{dm}^{-3} \mathrm{Mg}$ $\left(\mathrm{MgSO}_{4} .7 \mathrm{H}_{2} \mathrm{O}\right)$ were added 30 days after transplantation (DAT). The experiment was conducted for 130 days.

Plant height was assessed at the end of the experiment using a graduated ruler, and the plant shoots were then cut near the soil surface. The roots were manually separated from the soil, and the fresh mass (FM) of the shoots and roots was then measured using a precision balance.

Approximately $2.0 \mathrm{~g}$ of roots was clarified and stained with trypan blue (Koske and Gemma, 1989) to evaluate mycorrhizal colonization using the gridline intersect method (Giovannetti and Mosse, 1980), and $500 \mathrm{mg}$ of leaves was also reserved to assess the chlorophyll $a, b$, and total levels through extraction with $80 \%$ acetone (Lichtenthaler, 1987). The absorbances of the samples were assessed using a spectrophotometer at two different wavelengths: $663 \mathrm{~nm}$ for chlorophyll $a$ and $647 \mathrm{~nm}$ for chlorophyll $b$. The levels of chlorophyll $a, b$, and total chlorophyll were calculated using Eqs. (1), (2), and (3), respectively:

$$
\begin{aligned}
& \text { Chlorophyll } a\left(\mu \mathrm{g} \mathrm{g}^{-1} \mathrm{MF}\right)= \\
& \qquad\left[\left(12.25 \times \mathrm{A}_{663}\right)-\left(2.79 \times \mathrm{A}_{647}\right)\right] \times \mathrm{V} \\
& \text { Chlorophyll } b\left(\mu \mathrm{g} \mathrm{g}^{-1} \mathrm{MF}\right)= \\
& \quad\left[\left(12.50 \times \mathrm{A}_{647}\right)-\left(5.10 \times \mathrm{A}_{663}\right)\right] \times \mathrm{V}
\end{aligned}
$$

$$
\begin{aligned}
& \text { Total Chlorophyll }\left(\mu \mathrm{g} \mathrm{g}^{-1} \mathrm{MF}\right)= \\
& \qquad\left[\left(7.15 \times \mathrm{A}_{663}\right)+\left(18.71 \times \mathrm{A}_{647}\right)\right] \times \mathrm{V}
\end{aligned}
$$

where $\mathrm{A}$ is the absorbance and $\mathrm{V}$ is the sample volume $(\mathrm{mL})$.

The remaining shoot and root FM was dried in a forced-air oven at $65^{\circ} \mathrm{C}$ until reaching a constant mass. The production of dry matter (DM) was then assessed using a precision balance, and the material was ground and reserved. A portion of the roots and shoots was submitted to nitric perchloric digestion, and $\mathrm{Cu}$ was assessed by atomic absorption spectrophotometry (Tedesco et al., 1995). The remaining shoots and roots were submitted to sulfuric acid digestion, and the $\mathrm{P}$ levels in the extract were assessed using a spectrophotometer (Tedesco et al., 1995).

The percentage mycorrhizal colonization data were arcsine square-root transformed for homogenization of variance. Subsequently, all the data were submitted to an analysis of variance, and the Scott-Knott $(\mathrm{P}<0.05)$ test for mean separation was applied when the differences were statistically significant. A linear correlation analysis between the assessed variables was performed and is presented below when statistically significant.

\section{Results and Discussion}

Inoculation with the $R$. clarus and $R$. irregularis isolates promoted the greatest production of root DM in the young vines. Conversely, none of the AMF species affected the production of shoot DM, and the height increments of vines inoculated with $D$. heterogama and $A$. colombiana were less than in all the other treatments (Table 1).

The greater production of root DM in the $R$. clarus and $R$. irregularis treatments may have been caused by the ability of AMF to mitigate the stress caused by high soil $\mathrm{Cu}$

\begin{tabular}{|c|c|c|c|c|c|c|}
\hline \multirow[t]{2}{*}{$\mathrm{AMF}$} & \multicolumn{2}{|c|}{ Dry matter } & \multirow{2}{*}{$\begin{array}{l}\text { Height } \\
(\mathrm{cm})\end{array}$} & \multirow{2}{*}{$\begin{array}{l}\text { Chlorophyll } a \\
\left(\mu \mathrm{g} \mathrm{g}^{-1} \mathrm{MF}\right)\end{array}$} & \multirow{2}{*}{$\begin{array}{l}\text { Chlorophyll } b \\
\left(\mu \mathrm{g} \mathrm{g}^{-1} \mathrm{MF}\right)\end{array}$} & \multirow{2}{*}{$\begin{array}{l}\text { Total Chlorophyl } \\
\qquad\left(\mu \mathrm{g} \mathrm{g}^{-1} \mathrm{MF}\right)\end{array}$} \\
\hline & Shoots (g) & Roots (g) & & & & \\
\hline Non inoculated & $0.7 \mathrm{a}$ & $3.0 \mathrm{~b}$ & $10.8 \mathrm{a}$ & $294.40^{\mathrm{ns}}$ & $114.58^{\mathrm{ns}}$ & $408.98^{\mathrm{ns}}$ \\
\hline D. heterogama & $0.7 \mathrm{a}$ & $3.0 \mathrm{~b}$ & $9.0 \mathrm{~b}$ & 279.66 & 114.79 & 394.45 \\
\hline G. gigantea & $0.7 \mathrm{a}$ & $2.9 \mathrm{~b}$ & $10.9 \mathrm{a}$ & 353.57 & 126.81 & 480.38 \\
\hline A. morrowiae & $0.6 \mathrm{a}$ & $3.1 \mathrm{~b}$ & $11.6 \mathrm{a}$ & 299.53 & 112.54 & 412.07 \\
\hline A. colombiana & $0.7 \mathrm{a}$ & $2.8 \mathrm{~b}$ & $9.6 \mathrm{~b}$ & 314.48 & 113.08 & 427.56 \\
\hline R. clarus & $0.7 \mathrm{a}$ & $3.5 \mathrm{a}$ & $12.5 \mathrm{a}$ & 256.74 & 96.62 & 353.37 \\
\hline R. irregularis & $0.8 \mathrm{a}$ & $4.0 \mathrm{a}$ & $11.5 \mathrm{a}$ & 274.57 & 121.44 & 396.02 \\
\hline CV (\%) & 21.97 & 18.26 & 25.52 & 19.00 & 20.96 & 18.91 \\
\hline
\end{tabular}
levels (Ferrol et al., 2009; Saba et al., 2013), especially because those fungi promoted increased absorption of water and nutrients, particularly $\mathrm{P}$, through the roots, which con-

Table 1 - Shoot and root DM, plant height increment, and leaf chlorophyll $a, b$, and total levels in young vines from the P1103 rootstock with and without AMF inoculation in a soil with high Cu levels.

Data with the same letters in the same column are not significantly different according to the Scott-Knott test $(\mathrm{P}<0.05)$; ns $=$ not significant. 
tributed to the increased root system biomass (Gupta et al., 2014). Although plant root systems are known to be highly susceptible to excess $\mathrm{Cu}$ in the soil (Kopittke, et al., 2009), $R$. clarus and $R$. irregularis may play a key role in the protection of rootstocks after transplantation to soils contaminated with $\mathrm{Cu}$ and might facilitate the establishment and growth of seedlings during the crop cycle.

Vine growth may be reduced by increased soil levels of available $\mathrm{Cu}$, which was observed by Melo et al. (2008), who noted significant inhibition of biomass production of P1103 rootstock in a soil with $21.14 \mathrm{mg} \mathrm{kg}^{-1} \mathrm{Cu}$, a concentration two times less than the value found in the soil of the current experiment $\left(46.2 \mathrm{mg} \mathrm{kg}^{-1}\right)$. However, AMF may minimize these plant toxicity effects by increasing P nutrition (Soares and Siqueira, 2008; Andrade et al., 2010) as well as by other strategies, including the chelation of trace elements by organic compounds released into the soil or present in the plasma membrane interface and compartmentalization of $\mathrm{Cu}$ in spores and vesicles (Ferrol et al., 2009; Bedini et al., 2010; Cornejo et al., 2013). However, certain AMF and plant species may have no affinity (Nunes et al., 2013), which may be the cause of the growth at levels lower than the control plants in vines inoculated with $D$. heterogama or A. colombiana. Mycorrhizal symbiotic efficiency is known to vary among AMF and host plants (Moreira and Siqueira, 2006), which may be more evident in situations of stress, such as soil contamination with trace elements. Silva et al. (2006) observed that the benefits of
AMF inoculation for growth of $B$. decumbens in multicontaminated soil was independent of the origin of the fungal isolates from sites containing excess metals or not.

The contents of chlorophyll $a, b$, and total chlorophyll were not affected by the treatments (Table 1). High Cu levels within plants may cause decreased chlorophyll levels in plant leaves, which may be caused by the induction of iron $(\mathrm{Fe})$ deficiency by excess $\mathrm{Cu}$ in the plant tissues. When in excess, $\mathrm{Cu}$ may replace the central magnesium $(\mathrm{Mg})$ ion in the chlorophyll molecule, thereby inhibiting photosynthesis (Yruela, 2009). The levels of $\mathrm{Cu}$ absorbed by roots and transported to shoots presumably did not reduce the photosynthetic rate of young vines through that mechanism, with AMF affecting other evaluated parameters but not chlorophyll levels. This may have been caused by the high level of available $\mathrm{P}$ in the soil allowing good nutrition to the vines, which favors an increase in leaf area and plant biomass because the photosynthetic rate and chlorophyll $a$ and $b$ concentrations are increased in the leaves (Siqueira et al., 2008; Latef, 2011; Rahmaty and Khara, 2011).

The greatest percentage of mycorrhizal colonization in the roots of young vines was observed in plants inoculated with $R$. clarus or $R$. irregularis (with 44 and $43 \%$ colonized roots, respectively). All the other isolates also provided a good percentage of mycorrhization (25 to $35 \%$ colonization) (Figure 1).

The rates of root colonization found in this study were less than those recorded by Karagiannidis et al. (1997) in

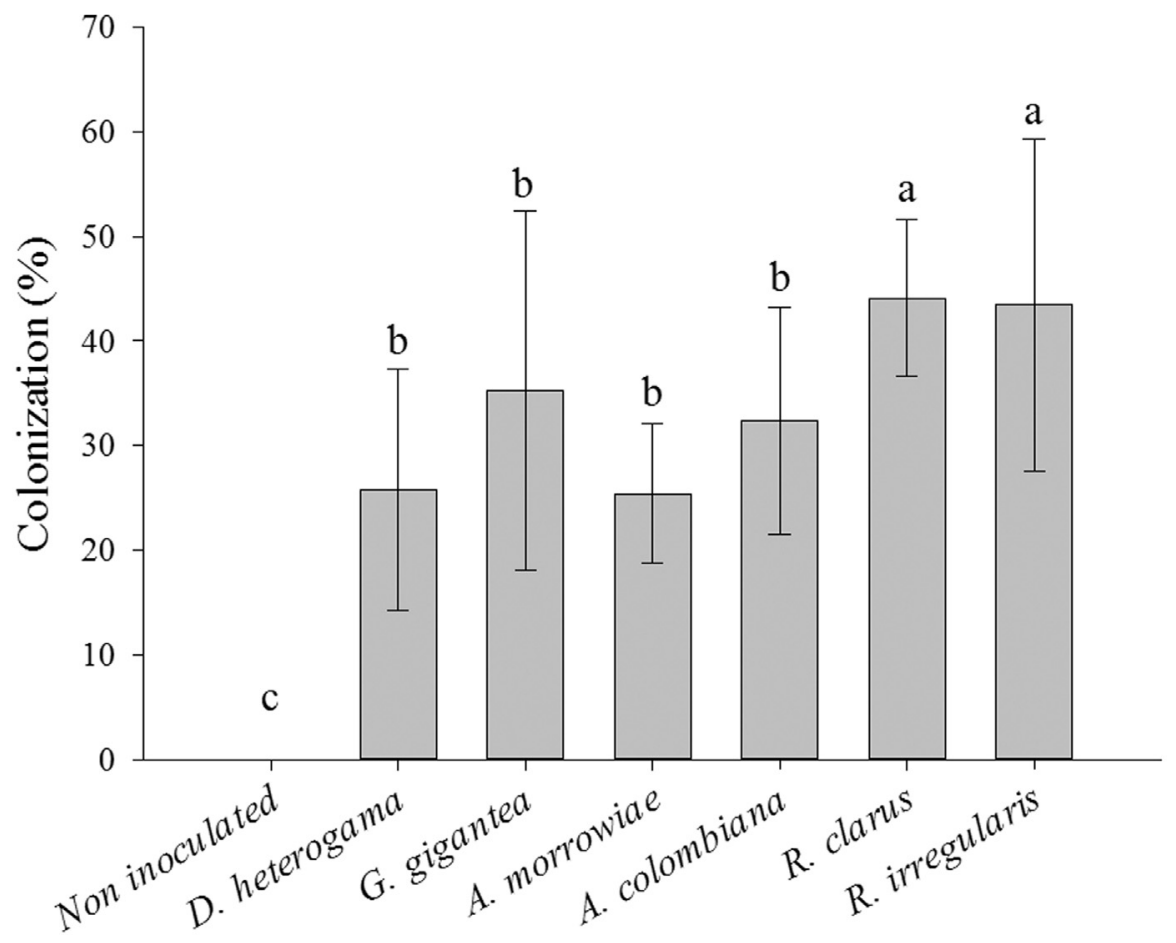

Figure 1 - Percentage of mycorrhizal colonization of young vines of the P1103 rootstock with and without AMF inoculation in soils with high Cu levels. 
roots of young vines of the $\mathrm{P} 1103$ rootstock, in which the lowest colonization rate was $75 \%$ in soil non-contaminated with trace elements. Mycorrhizal association with plant roots may be stimulated when nutrient deficiency occurs in soils, especially deficiency of $\mathrm{P}$ and micronutrients, whereas mycorrhization is not favored in more fertile soils (Hippler and Moreira, 2013). In this study, although high levels of $\mathrm{P}$ were available in the soil $\left[28.4 \mathrm{mg} \mathrm{kg}^{-1}\right.$, according to CQFS-RS/SC (2004)], the root colonization ranged from 26 to $44 \%$, and these values were commonly found for vines in substrates with low P (Zemke et al., 2003). Furthermore, soil contamination is known to have an outstanding effect on the reduction of mycorrhizal colonization (Klauberg-Filho et al., 2005; Zhang et al., 2012). Karagiannidis and Nikolaou (2000) observed that the addition of $\mathrm{Pb}\left(300 \mathrm{mg} \mathrm{kg}^{-1}\right)$ reduced mycorrhization from 68.7 to $26.3 \%$ and the addition of $\mathrm{Cd}\left(50 \mathrm{mg} \mathrm{kg}^{-1}\right)$ reduced mycorrhization from 58.0 to $44.7 \%$ in grapevines. However, reference values for mycorrhizal colonization in soils with high levels of $\mathrm{Cu}$ are not available for vines.

With the exception of D. heterogama, all the AMF isolates increased the shoot $\mathrm{P}$ levels, which were 39\% greater than the control on average (Table 2). Additionally, the greatest root $\mathrm{P}$ levels were found when young vines were inoculated with $G$. gigantea, A. morrowiae, $R$. clarus, or $R$. irregularis (Table 2), which presented a $27 \%$ increase in root $\mathrm{P}$ levels on average compared with the control. Inoculation with $D$. heterogama or $A$. colombiana did not cause an increase in the root $\mathrm{P}$ levels of the vines.

The greatest shoot $\mathrm{P}$ accumulation was observed in young vines inoculated with $R$. irregularis, followed by $G$. gigantea, A. colombiana, and $R$. clarus, and the lowest shoot $\mathrm{P}$ accumulation was found in young vines inoculated with $D$. heterogama or $A$. morrowiae or without inoculation (Table 2). The greatest root $\mathrm{P}$ accumulation was noted in plants inoculated with $R$. clarus or $R$. irregularis (Table 2), which may be related to the greater increase in root and shoot DM of plants inoculated with those species
(Table 1). Such increases occur because plants can modify their root systems to increase nutrient absorption and the number of root branches and hairs and elongate their roots, thereby increasing the root:shoot biomass ratio (Gupta et $a l ., 2014)$, with such changes observed in plants from all treatments. This natural ability of plants and mycorrhizal associations - especially in those inoculated with $R$. clarus or $R$. irregularis in this study - enables an even greater increase in the root system, promotes the establishment of the plants in the soil and mitigates stressful situations.

The linear correlation between shoot $\mathrm{P}$ accumulation and colonization percentage was significant $(r=0.80$; $\mathrm{P}<0.05)$ and may be related to the affinity of the particular AMF isolates for the plant (Nunes et al., 2013). This correlation partly explains the difference in nutrient accumulation in the shoots of the plants in the different treatments and indicates that AMF isolates with a greater capacity for root colonization contribute to improved $\mathrm{P}$ nutritional status in young vines, which is important in soils with high levels of trace elements because the improvement in P nutritional status by AMF promotes the growth of plants exposed to high concentrations of trace elements, including $\mathrm{Cu}$ and $\mathrm{Zn}$ (Andrade et al., 2010).

The shoot $\mathrm{P}$ accumulation was not correlated with accumulated DM, and this result is inconsistent with root $\mathrm{P}$ accumulation, which was positively linearly correlated with root accumulated DM $(\mathrm{r}=0.83 ; \mathrm{P}<0.05)$. However, this lack of correlation was most likely caused by the failure of inoculation with AMF isolates to promote an increase in shoot DM (Table 1). These results corroborate those of Zemke et al. (2003) and Anzanello et al. (2011), who noted that AMF inoculation failed to promote increased DM of the $\mathrm{P} 1103$ rootstock after acclimatization.

The highest shoot $\mathrm{Cu}$ levels were found in young vines inoculated with $A$. morrowiae or $R$. clarus, which increased the shoot $\mathrm{Cu}$ levels by 35 and $44 \%$ relative to that of the control plants, respectively (Table 3 ). The highest root $\mathrm{Cu}$ levels were found in plants inoculated with G. gigantea,

Table 2 - Root and shoot P levels and accumulation in young vines of the P1103 rootstock with and without AMF inoculation in a soil with high Cu levels.

\begin{tabular}{|c|c|c|c|c|}
\hline \multirow[t]{2}{*}{ AMF } & \multicolumn{2}{|c|}{$\mathrm{P}$ levels } & \multicolumn{2}{|c|}{$\mathrm{P}$ accumulation } \\
\hline & Roots ( $\left.\mathrm{mg} \mathrm{kg}^{-1}\right)$ & Shoots $\left(\mathrm{mg} \mathrm{kg}^{-1}\right)$ & Roots $\left(\mu \mathrm{g}\right.$ plant $\left.^{-1}\right)$ & Shoots $\left(\mu\right.$ plant $\left.^{-1}\right)$ \\
\hline Non inoculated & $1.3 \mathrm{~b}$ & $1.7 \mathrm{~b}$ & $4.2 \mathrm{c}$ & $1.2 \mathrm{c}$ \\
\hline D. heterogama & $1.2 \mathrm{~b}$ & $1.8 \mathrm{~b}$ & $3.9 \mathrm{c}$ & $1.3 \mathrm{c}$ \\
\hline G. gigantea & $1.7 \mathrm{a}$ & $2.4 \mathrm{a}$ & $5.2 \mathrm{~b}$ & $1.9 \mathrm{~b}$ \\
\hline A. morrowiae & $1.6 \mathrm{a}$ & $2.4 \mathrm{a}$ & $5.4 \mathrm{~b}$ & $1.5 \mathrm{c}$ \\
\hline A. colombiana & $1.4 \mathrm{~b}$ & $2.5 \mathrm{a}$ & $4.0 \mathrm{c}$ & $1.8 \mathrm{~b}$ \\
\hline R. clarus & $1.7 \mathrm{a}$ & $2.3 \mathrm{a}$ & $6.8 \mathrm{a}$ & $1.8 \mathrm{~b}$ \\
\hline R. irregularis & $1.6 \mathrm{a}$ & $2.7 \mathrm{a}$ & $6.8 \mathrm{a}$ & $2.4 \mathrm{a}$ \\
\hline CV (\%) & 8.76 & 21.11 & 8.71 & 14.99 \\
\hline
\end{tabular}

Data with the same letters in the same column were not significantly different according to the Scott-Knott test $(\mathrm{P}<0.05)$. 
Table 3 - Root and shoot Cu levels and accumulation in young vines of the P1103 rootstock with and without AMF inoculation in soil with high Cu levels.

\begin{tabular}{lccccc}
\hline \multirow{2}{*}{ AMF } & \multicolumn{2}{c}{ Cu levels } & & \multicolumn{2}{c}{ Cu accumulation } \\
\cline { 2 - 3 } \cline { 5 - 6 } \cline { 5 - 5 } Noots $\left(\mathrm{mg} \mathrm{kg}^{-1}\right)$ & Shoots $\left(\mathrm{mg} \mathrm{kg}^{-1}\right)$ & & Roots $\left(\mu \mathrm{g} \mathrm{plant}^{-1}\right)$ & Shoots $\left(\mu \mathrm{g} \mathrm{plant}^{-1}\right)$ \\
\hline Non inoculated & $23.8 \mathrm{~b}$ & $3.4 \mathrm{~b}$ & & $73.6 \mathrm{~d}$ & $2.4 \mathrm{c}$ \\
D. heterogama & $29.9 \mathrm{~b}$ & $2.6 \mathrm{~b}$ & & $93.1 \mathrm{c}$ & $1.9 \mathrm{c}$ \\
G. gigantea & $34.2 \mathrm{a}$ & $3.2 \mathrm{~b}$ & & $101.8 \mathrm{c}$ & $2.4 \mathrm{c}$ \\
A. morrowiae & $41.2 \mathrm{a}$ & $4.6 \mathrm{a}$ & & $129.9 \mathrm{~b}$ & $2.9 \mathrm{~b}$ \\
A. colombiana & $35.0 \mathrm{a}$ & $2.8 \mathrm{~b}$ & & $103.0 \mathrm{c}$ & $2.1 \mathrm{c}$ \\
R. clarus & $40.9 \mathrm{a}$ & $4.9 \mathrm{a}$ & & $160.3 \mathrm{a}$ & $3.8 \mathrm{a}$ \\
R. irregularis & $32.6 \mathrm{~b}$ & $3.2 \mathrm{~b}$ & & $132.9 \mathrm{~b}$ & $2.8 \mathrm{~b}$ \\
CV $(\%)$ & 23.64 & 36.34 & & 13.8 & 21.3 \\
\hline
\end{tabular}

Data with the same letters in the same column are not significantly different according to the Scott-Knott test $(\mathrm{P}<0.05)$

A. morrowiae, A. colombiana, or R. clarus, which promoted an average increase in root $\mathrm{Cu}$ levels of 59\% (Table 3). The effects of AMF inoculation on the uptake of trace elements by the host plant depend greatly on the concentration in the ground. The AMF increased uptake when the concentration of trace elements in the soil was below the critical concentration for mycorrhizal symbiosis, whereas above this point, uptake and translocation of trace elements to the shoots were inhibited (Christie et al., 2004). Therefore, increased concentrations of $\mathrm{Cu}$ and other nutrients in plant tissue are somewhat expected in mycorrhized plants because AMF assist in the absorption of soil nutrients, and the results presented here corroborate the results of Andrade et al. (2010), who noted an increase in the concentrations of nutrients, including $\mathrm{Cu}$, caused by mycorrhizal associations of young coffee plants grown in a high Cu soil.

This limited $\mathrm{Cu}$ absorption by young vines inoculated with AMF could also be expected because several species of these fungi have strategies to suppress the absorption of trace elements from contaminated soils. For example, high levels of trace elements may also cause stress to the fungi themselves, although mycorrhizae may store $\mathrm{Cu}$ in cellular compartments with reduced metabolism, including spores and vesicles, to ensure their own survival, and this sequestration also benefits the plants with which they are associated (Ferrol et al., 2009; Cornejo et al., 2013). Furthermore, AMF may release organic substances, including glomalin, to decrease the availability of heavy metals in soils (Bedini et al., 2010). Those organic substances bind to metals and form a complex that may not be absorbed by plants, further decreasing metal concentrations in the plant tissues. However, an increase in $\mathrm{Cu}$ levels was observed in both roots and shoots, which was not high enough to cause toxicity to the vines. According to Kabata-Pendias (2011), Cu levels in plant leaves between 5 and $30 \mathrm{mg} \mathrm{kg}^{-1}$ are generally con- sidered normal, and levels between 20 and $100 \mathrm{mg} \mathrm{kg}^{-1}$ are generally considered toxic.

The mean ratio between $\mathrm{Cu}$ levels in plant roots and shoots was 6.9 in the control, whereas the mean ratio was greater in all AMF treatments and ranged from 8.3 to 12.4 , indicating that only a small portion of root $\mathrm{Cu}$ was translocated to the leaves and stem of the young vines. This contrast may have occurred because of $\mathrm{P}$ absorption by the roots, which was promoted by the AMF (Andrade et al., 2010) and may cause the formation of less mobile metal-phosphate compounds in plants, thus reducing the translocation of trace elements from the roots to the shoots (Soares and Siqueira, 2008).

Plants exposed to high $\mathrm{Cu}$ levels generally accumulate greater amounts of trace elements in their roots because the initial contact of the plants with $\mathrm{Cu}$ occurs through roots exposed to the element in the soil (Kopittke et al., 2009). Furthermore, plants may also have natural strategies to decrease the transport of excess $\mathrm{Cu}$ and other metals to the shoots, including compartmentalization in the vacuoles, where metabolism is reduced; chelation in the plasma membrane; and intracellular complexation by organic substances, thus avoiding or decreasing toxicity effects (Yruela, 2009; Saba et al., 2013).

The greatest accumulation of $\mathrm{Cu}$ in both the shoots and roots was found in plants inoculated with the fungus $R$. clarus, followed by plants treated with $A$. morrowiae and $R$. irregularis, whereas plants inoculated with other fungi and those without inoculation accumulated the lowest amount of $\mathrm{Cu}$ (Table 3). The greatest accumulation levels primarily resulted from the greater $\mathrm{Cu}$ levels in the roots and shoots of the plants from those treatments. The greatest accumulations of $\mathrm{Cu}$ in those treatments may also have been caused by the positive correlation with $\mathrm{P}$ accumulation in the same organ ( $\mathrm{r}=0.87 ; \mathrm{P}<0.01)$, a correlation that was especially strong in the roots, although the greatest $\mathrm{Cu}$ accumulation occurred in the vine shoots. Thus, the increased root $\mathrm{P}$ con- 
tributed to the increased root biomass and enabled greater absorption of water and nutrients, including $\mathrm{Cu}$, by the plant (Gupta et al., 2014).

\section{Conclusions}

Rhizophagus clarus and $R$. irregularis isolates enable high mycorrhizal colonization of vine roots and improve $\mathrm{P}$ absorption and root growth of young vine plants in soil with high $\mathrm{Cu}$ levels.

AMF inoculation increased $\mathrm{Cu}$ absorption by young vine plants, although most of the $\mathrm{Cu}$ was retained in the roots of the mycorrhized plants, thus reducing toxicity in the plant shoots.

The contents of chlorophyll were not affected by AMF inoculation.

\section{References}

Andrade SAL, Silveira APD, Mazzafera P (2010) Arbuscular mycorrhiza alters metal uptake and the physiological response of Coffea arabica seedlings to increasing $\mathrm{Zn}$ and $\mathrm{Cu}$ concentrations in soil. Sci Total Environm 408:5381-5391.

Anzanello R, Souza PVD, Casamali B (2011) Fungos micorrízicos arbusculares (FMA) em porta-enxertos micropropagados de videira. Bragantia 70:409-415.

Bedini S, Turrini A, Rigo C et al. (2010) Molecular characterization and glomalin production of arbuscular mycorrhizal fungi colonizing a heavy metal polluted ash disposal island, downtown Venice. Soil Biol Biochem 42:758-765.

Brunetto G, Miotto A, Ceretta CA et al. (2014) Mobility of copper and zinc fractions in fungicide amended vineyard sandy soils. Arch Agron Soil Sci 60:609-624.

Campos LP, Leite LFC, Maciel GA et al. (2013) Estoques e frações de carbono orgânico em Latossolo Amarelo submetido a diferentes sistemas de manejo. Pesqui Agropec Bras 48:304-312.

Chivenge P, Vanlauwe B, Gentile R et al. (2011) Comparison of organic $v s$. mineral resource effects on short-term aggregate carbon and nitrogen dynamics in a sandy soil $v s$. a fine textured soil. Agr Ecosyst Environm 140:361-371.

Christie P, Li X, Chen B (2004) Arbuscular mycorrhiza can depress translocation of zinc to shoots of host plants in soils moderately polluted with zinc. Plant Soil 261:209-217.

Cornejo P, Pérez-Tienda J, Meier S et al. (2013) Copper compartmentalization in spores as a survival strategy of arbuscular mycorrhizal fungi in $\mathrm{Cu}$-polluted environments. Soil Biol Biochem 57:925-928.

CQFS-RS/SC (2004) Manual de Adubação e Calagem para os Estados do Rio Grande do Sul e de Santa Catarina. 10 ed. SBCS - Núcleo Regional Sul/UFRGS, Porto Alegre.

EMBRAPA (1999) Manual de análises químicas de solos, plantas e fertilizantes. 2 ed. EMBRAPA Solos: Rio de Janeiro.

Ferrol N, González-Guerrero M, Valderas A et al. (2009) Survival strategies of arbuscular mycorrhizal fungi in Cu-polluted environments. Phytochem Rev 8:551-559.

Ferrol N, Pérez-Tienda J (2009) Coordinated Nutrient Exchange in Arbuscular Mycorrhiza. In: Azcón-Aguilar C, Barea JM, Gianinazzi S, Gianinazzi-Pearson V (eds). Mycorrhizas -
Functional Processes and Ecological Impact. Springer, pp 73-88.

Galzy R (1964) Technique de thermothérapie des viroses de la vigne. Ann Épiphyt 15:245-256.

Giovannetti M, Mosse B (1980) An evaluation of techniques for measuring vesicular-arbuscular mycorrhizal infection in roots. New Phytol 84:484-500.

Gupta DK, Chatterjee S, Datta S et al. (2014) Role of phosphate fertilizers in heavy metal uptake and detoxification of toxic metals. Chemosphere 108:134-144.

Hippler FWR, Moreira M (2013) Dependência micorrízica do amendoinzeiro sob doses de fósforo. Bragantia 72:184-191.

Kabata-Pendias A (2011) Trace Elements in Soils and Plants. 4 ed. CRC Press, Boca Raton.

Karagiannidis N, Nikolaou N (2000) Influence of arbuscular mycorrhizae on heavy metal $(\mathrm{Pb}$ and $\mathrm{Cd})$ uptake, growth, and chemical composition of Vitis vinifera L. (cv. Razaki). Am J Enol Vitic 51:269-275.

Karagiannidis N, Velemis D, Stavropoulos N (1997) Root colonization and spore population by VA-mycorrhizal fungi in four grapevine rootstocks. Vitis 36:57-60.

Klauberg-Filho O, Siqueira JO, Moreira FMS et al. (2005) Ecologia, função e potencial de aplicação de fungos micorrízicos arbusculares em condições de excesso de metais pesados. Tópicos em Ciência do Solo 4:85-144.

Kopittke PM, Asher CJ, Blamey FPC et al. (2009) Toxic effects of $\mathrm{Cu}^{2+}$ on growth, nutrition, root morphology, and distribution of $\mathrm{Cu}$ in roots of Sabi grass. Sci Total Environm 407:46164621.

Koske RE, Gemma JN (1989) A modified procedure for staining roots to detect V-A mycorrhizas. Mycol Res 92:486-505.

Latef AAHA (2011) Influence of arbuscular mycorrhizal fungi and copper on growth, accumulation of osmolyte, mineral nutrition and antioxidant enzyme activity of pepper (Capsicum annuum L.). Mycorrhiza, 21:495-503.

Lequeux H, Hermans C, Lutts S et al. (2010) Response to copper excess in Arabidopsis thaliana: Impact on the root system architecture, hormone distribution, lignin accumulation and mineral profile. Plant Physiol Biochem 48:673-682.

Lichtenthaler HK (1987) Chlorophylls and carotenoids: Pigments of photosynthetic biomembranes. Methods Enzymol 148:350-382.

Melo GW, Brunetto G, Schafer Junior A et al. (2008) Matéria seca e acumulação de nutrientes em videiras jovens cultivadas em solos com diferentes níveis de cobre. R Bras Agrociência 14:72-76.

Michaud AM, Chappellaz C, Hinsinger P (2008) Copper phytotoxicity affects root elongation and iron nutrition in durum wheat (Triticum turgidum durum L.). Plant Soil 310:151165.

Moreira FMS, Siqueira JO (2006) Microbiologia e bioquímica do solo. UFLA, Lavras.

Nogueirol RC, Alleoni LRF, Nachtigall GR et al. (2010) Sequential extraction and availability of copper in $\mathrm{Cu}$ fungicideamended vineyard soils from Southern Brazil. J Hazard Mater 181:931-937.

Nunes JLS, Souza PVD, Marodin GAB et al. (2013) Desenvolvimento de plântulas de pessegueiro 'Okinawa' inoculadas com micorrizas arbusculares isoladas de pomares de pessegueiros e de vinhedos. Rev Bras Frutic 35:845-852. 
Rahmaty R, Khara J (2011) Effects of vesicular arbuscular mycorrhiza Glomus intraradices on photosynthetic pigments, antioxidant enzymes, lipid peroxidation, and chromium accumulation in maize plants treated with chromium. Turk J Biol 35:51-58.

Resh HM (1997) Cultivos Hidropónicos: Nuevas Técnicas de Producción. 4. ed. Mundi-Prensa Libros, Madrid.

Saba H, Jyoti P, Neha S (2013) Mycorrhizae and phytochelators as remedy in heavy metal contaminated land remediation. Int Res J Environm Sci 2:74-78.

Sheldon AR, Menzies NW (2005) The effect of copper toxicity on the growth and root morphology of Rhodes grass (Chloris gayana Knuth.) in resin buffered solution culture. Plant Soil 278:341-349.

Silva S, Siqueira JO, Soares CRFS (2006) Fungos micorrízicos no crescimento e na extração de metais pesados pela braquiária em solo contaminado. Pesq Agropec Bras 41:1749-1757.

Siqueira JO, Soares CRFS, Silva CA (2008) Matéria orgânica em solos de áreas degradadas. In: Santos GA, Silva LS, Canellas LP, Camargo FAO (eds.). Fundamentos da matéria orgânica do solo: Ecossistemas tropicais e subtropicais. Metropole, Porto Alegre, pp 495-524.
Soares CRFS, Siqueira JO (2008) Mycorrhiza and phosphate protection of tropical grass species against heavy metal toxicity in multi-contaminated soil. Biol Fertil Soils 44:833-841.

Soil Survey Staff (2006) Keys to Soil Taxonomy, 10 ed. USDASCS, Washington.

Tedesco MJ, Gianello C, Bissani CA et al. (1995) Análises de Solo, Plantas e Outros Materiais. 2 ed. UFRGS, Porto Alegre.

Yruela I (2009) Copper in plants: acquisition, transport and interactions. Funct Plant Biol 36:409-430.

Zemke JM, Pereira F, Lovato PE et al. (2003) Avaliação de substratos para inoculação micorrízica e aclimatização de dois porta-enxertos de videira micropropagados. Pesqui Agropec Bras 38:1309-1315.

Zhang XH, Wang YS, Lin AJ (2012) Effects of arbuscular mycorrhizal colonization on the growth of upland rice (Oryza sativa L.) in soil experimentally contaminated with $\mathrm{Cu}$ and $\mathrm{Pb}$. Clinic Toxicol S3:1-5.

Associate Editor: Fernando Dini Andreote

All the content of the journal, except where otherwise noted, is licensed under a Creative Commons License CC BY-NC. 